Article

\title{
Field Test of In Situ Groundwater Treatment Applying Oxygen Diffusion and Bioaugmentation Methods in an Area with Sustained Total Petroleum Hydrocarbon (TPH) Contaminant Flow
}

\author{
Artem Demenev ${ }^{1, *}$, Nikolay Maksimovich ${ }^{1}$, Vadim Khmurchik ${ }^{1}$, Gennadiy Rogovskiy ${ }^{2}$, Anatoliy Rogovskiy ${ }^{2}$ \\ and Alexey Baryshnikov ${ }^{2}$ \\ 1 Institute of Natural Science, Perm State University, Genkel St. 4, 614990 Perm, Russia; \\ nmax54@gmail.com (N.M.); khmurchik.vadim@mail.ru (V.K.) \\ 2 Laboratory of Non-Destructive Control, Limited Liability Company (LLC), Revolution St. 12, Office 41, \\ 614007 Perm, Russia; g.rogovski@loggers.ru (G.R.); A.Rogovski@loggers.ru (A.R.); \\ a.baryshnikov@loggers.ru (A.B.) \\ * Correspondence: demenevartem@gmail.com
}

check for updates

Citation: Demenev, A.; Maksimovich, N.; Khmurchik, V.; Rogovskiy, G.; Rogovskiy, A.; Baryshnikov, A. Field Test of In Situ Groundwater Treatment Applying Oxygen Diffusion and Bioaugmentation Methods in an Area with Sustained Total Petroleum Hydrocarbon (TPH) Contaminant Flow. Water 2022, 14, 192. https://doi.org/10.3390/ w14020192

Academic Editor: Efthimia A. Kaprara

Received: 1 December 2021 Accepted: 31 December 2021 Published: 11 January 2022

Publisher's Note: MDPI stays neutral with regard to jurisdictional claims in published maps and institutional affiliations.

Copyright: (C) 2022 by the authors. Licensee MDPI, Basel, Switzerland. This article is an open access article distributed under the terms and conditions of the Creative Commons Attribution (CC BY) license (https:// creativecommons.org/licenses/by/ $4.0 /)$.

\begin{abstract}
Contamination of groundwater by petroleum hydrocarbons is a widespread environmental problem in many regions. Contamination of unsaturated and saturated zones could also pose a significant risk to human health. The main purpose of the study was to assess the efficiency of biodegradation of total petroleum hydrocarbon (TPH) in situ, in an area with loam and sandy loam soils, and to identify features and characteristics related to groundwater treatment in an area with a persistent flow of pollutants. We used methods of biostimulation (oxygen as stimulatory supplement) and bioaugmentation to improve water quality. Oxygen was added to the groundwater by diffusion through silicone tubing. The efficiency of groundwater treatment was determined by detailed monitoring. Implementation of the applied measure resulted in an average reduction in $\mathrm{TPH}$ concentration of $73.1 \%$ compared with the initial average concentration $(4.33 \mathrm{mg} / \mathrm{L})$, and in the local area, TPH content was reduced by $95.5 \%$. The authors hope that this paper will contribute to a better understanding of the topic of groundwater treatment by in situ biodegradation of TPH. Further studies on this topic are particularly needed to provide more data and details on the efficiency of groundwater treatment under adverse geological conditions.
\end{abstract}

Keywords: groundwater; contamination; total petroleum hydrocarbon (TPH); biodegradation; oxygen diffusion; field test

\section{Introduction}

Environmental protection measures in the oil industry contribute a certain component to the concept of sustainable development. Implementing these measures leads to the prevention or decrease in pollution in the environment. However, petroleum hydrocarbon contamination in groundwater is still a common ecological challenge in many regions of the world [1,2].

The formation of petroleum hydrocarbon contamination in unsaturated and saturated zones may represent a risk to human health and have an extremely negative impact on components of the environment: groundwater, surface water, soil and bottom sediments, vegetation, etc. [3]. Additionally, it leads to the degradation of large areas and significantly complicates the use of natural resources.

The main cause of this contamination is accidental leakage from tanks and pipes used in the oil industry. In an emergency, hydrocarbons usually form persistent contamination (non-aqueous phase liquids (NAPLs)) [4], which spreads from the point source downward into the soil, frequently reaching groundwater. Subsequently, dissolved hydrocarbon plumes form, with relatively fast transport along with the groundwater flow [5-7]. In 
some cases, the spreading of the dissolved phase can continue for a long time [8] even after the implementation of environmental protection measures, such as pumping out the non-aqueous phase liquid [9-11]. Therefore, it is especially important to improve and apply technologies aimed at preventing the spread of dissolved hydrocarbon plumes in groundwater.

Environmental activities in the oil industry involve the implementation of various methods and technical means [12-14]. In general, the methods of preventing pollution can be divided into several groups: mechanical, physical, chemical, biological, and a mix of these, for example, constructed wetlands $[15,16]$. In the case of dissolved petroleum hydrocarbons, the biological destruction of contamination is one of the most effective and common approaches applied in industry [17-19]. The biological treatment (bioremediation) of contaminated groundwater and soils is based on the natural capability of microorganisms to degrade hydrocarbons [20-22]. Along with bioremediation under monitored natural attenuation (MNA), for faster results, additional solutions are often applied. Biostimulation and bioaugmentation approaches are applied to degrade hydrocarbons in the environment [23]. Biostimulation is based on the principle of creating optimal conditions for the growth of native hydrocarbon-destroying microflora. This growth can be limited by low temperature, excess acidity, and a lack of oxygen and other elements (for example, nitrogen and phosphorus) necessary for microorganisms [24,25]. Bioaugmentation involves the addition of microorganisms to the environment [26-28] and can be used as a separate method of reducing petroleum hydrocarbon contamination, and is also often used in conjunction with biostimulation [29]. Numerous studies have shown that hydrocarbons, such as alkanes, aromatic hydrocarbons, polycyclic aromatic hydrocarbons, ethers, acids, and various mixtures of hydrocarbons, can be destroyed by microorganisms inhabiting groundwater and soil [30-32].

Hydrocarbon contamination can be treated ex situ, i.e., on special sites [33,34], or in situ, i.e., at the place of contamination [35]. In situ methods are in many cases more affordable and efficient compared with methods that require the extraction and transportation of contaminated components to the place of treatment [22].

The research objective of the study was to assess the efficiency of TPH biodegradation of in situ, in an area with loam and sandy loam soils, and to identify features and characteristics related to groundwater treatment in an area with a persistent flow of pollutants. Examples of successful application of in situ cleaning methods are shown in many studies [36-38], including biostimulation activity with oxygen accelerating the destruction of contamination in the saturation zone [39-41]. In this way, the median rate of treatment from aromatic hydrocarbons was shown to be $85-96 \%$ [42]. Oxygen biostimulation, together with bioaugmentation, has been particularly successful against methyl tert-butyl ether (MTBE) contamination [43-45].

However, implementation of groundwater treatment occurs mostly at sites with sandy soil. These methods are rarely applied at sites with loam and sandy loam soils, and are of high interest to potential consumers and researchers. In this study, we tested the in situ technology of groundwater treatment of dissolved petroleum hydrocarbons using biostimulation and bioaugmentation. The authors hope that this paper will contribute to a better understanding of groundwater treatment by in situ biodegradation of TPH.

Waterloo emitters were used to introduce oxygen into the groundwater as stimulating additives. These emitters have been successfully used to stimulate the growth of hydrocarbon-destroying microorganisms [46,47]. In our case, to increase the efficiency of groundwater purification, we also performed bioaugmentation with indigenous microorganisms isolated from the soil and groundwater of the contaminated site.

\section{Study Area}

Test trials of the water treatment were carried out at the site close to the oil refinery plant located in the Volga Federal District, Russian Federation. The plant has been operating for more than 50 years. During its long operation, petroleum hydrocarbon contamination 
has formed in the unsaturated and saturated zones. In accordance with the specifics of the plant, the contamination is a mixture of various petroleum hydrocarbons: products of oil refining, gasoline, diesel fuel, engine oils, etc. Despite the successful measures taken to pump NAPL (and water) and the operation of a drainage system to intercept contaminated groundwater, the spreading of a dissolved hydrocarbons plume can be traced. The test trial area (remediation site) was located between the drainage system and a river, into which contaminated groundwater is discharged (Figure 1).

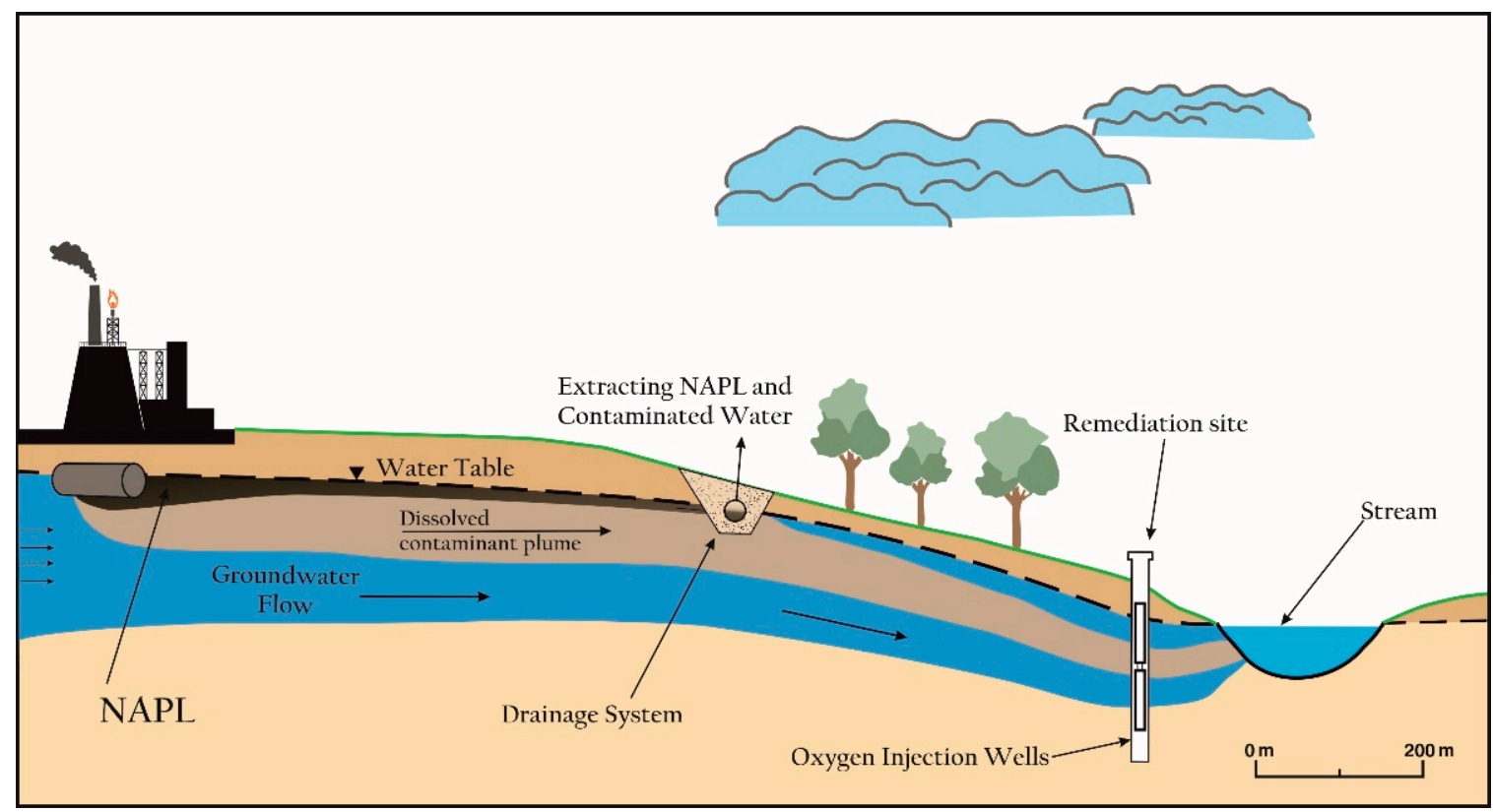

Figure 1. Concept view of contaminant transport in groundwater at test site.

Hydrology and climate. The test site is located $100 \mathrm{~m}$ from a small river and has a slightly sloped surface toward the stream. The river is $22 \mathrm{~km}$ long, the contribution of snowmelt to streamflow in the river reaches $60-65 \%$, and the rate of streamflow near the remediation site varies from $0.311 \mathrm{~m}^{3} / \mathrm{s}$ (August) to $0.708 \mathrm{~m}^{3} / \mathrm{s}$ (May). The hydrochemical type of the river water is $\mathrm{HCO}_{3}-\mathrm{Ca}$, and TDS ranges from 0.36 to $0.82 \mathrm{ppm}$. Anthropogenic activities in the river basin area impact water quality: three petrochemical industry plants are located here. The concentration of total petroleum hydrocarbon (TPH) reaches $0.51 \mathrm{mg} / \mathrm{dm}^{3}$, caused by the discharge of contaminated groundwater to the river. This issue required the removal of contaminants from the groundwater using bioremediation as a treatment method and led to the designed test site.

The climate of the study area is temperate continental with cold snowy winters, late spring frosts, warm and relatively short summers, and early autumns. The average annual temperature is $+2.1^{\circ} \mathrm{C}$ and the average annual precipitation is $616-634 \mathrm{~mm}$.

Geology and hydrogeology. The local geological section consists of (from top to bottom) technogenic, alluvial, and alluvial-deluvial deposits of Quaternary age, with bedrock deposits of Lower Permian age. Technogenic deposits are widespread here, and their thickness reaches $2.0 \mathrm{~m}$. Alluvial and alluvial-deluvial deposits forming the river bank section, floodplain, and slopes mainly consist of loam, sandy loam, sand, and gravel, and the thickness of the layer is 4.5-14 m. Bedrock underlies the Quaternary deposits and consists of weathered sandstone, mudstone, and siltstone.

Field tests were carried out in the area of the river floodplain, where the groundwater table is variable and can range from $0.5-2.7 \mathrm{~m}$ depending on the local topography and the season. This unconfined aquifer is mainly composed of sandy clay loam and sandy loam. The contaminated aquifer is recharged predominantly by infiltrating precipitation, and an additional source is water inflow from the underlying aquifer. The groundwater 
flow is directed toward the river with flow velocity $0.2-0.6 \mathrm{~m} /$ day. In general, the chemical composition of the groundwater in the treatment wells was quite homogeneous (as shown in the diagram in Figure 2), with hydrochemical type $\mathrm{HCO}_{3}-\mathrm{Ca}$ and TDS of about $1000 \mathrm{ppm}$. Elevated values of total hardness, $\mathrm{Fe}, \mathrm{Mg}$, and trace elements $(\mathrm{Mn}, \mathrm{As}, \mathrm{Pb}$, etc.) were revealed in water samples from several wells.

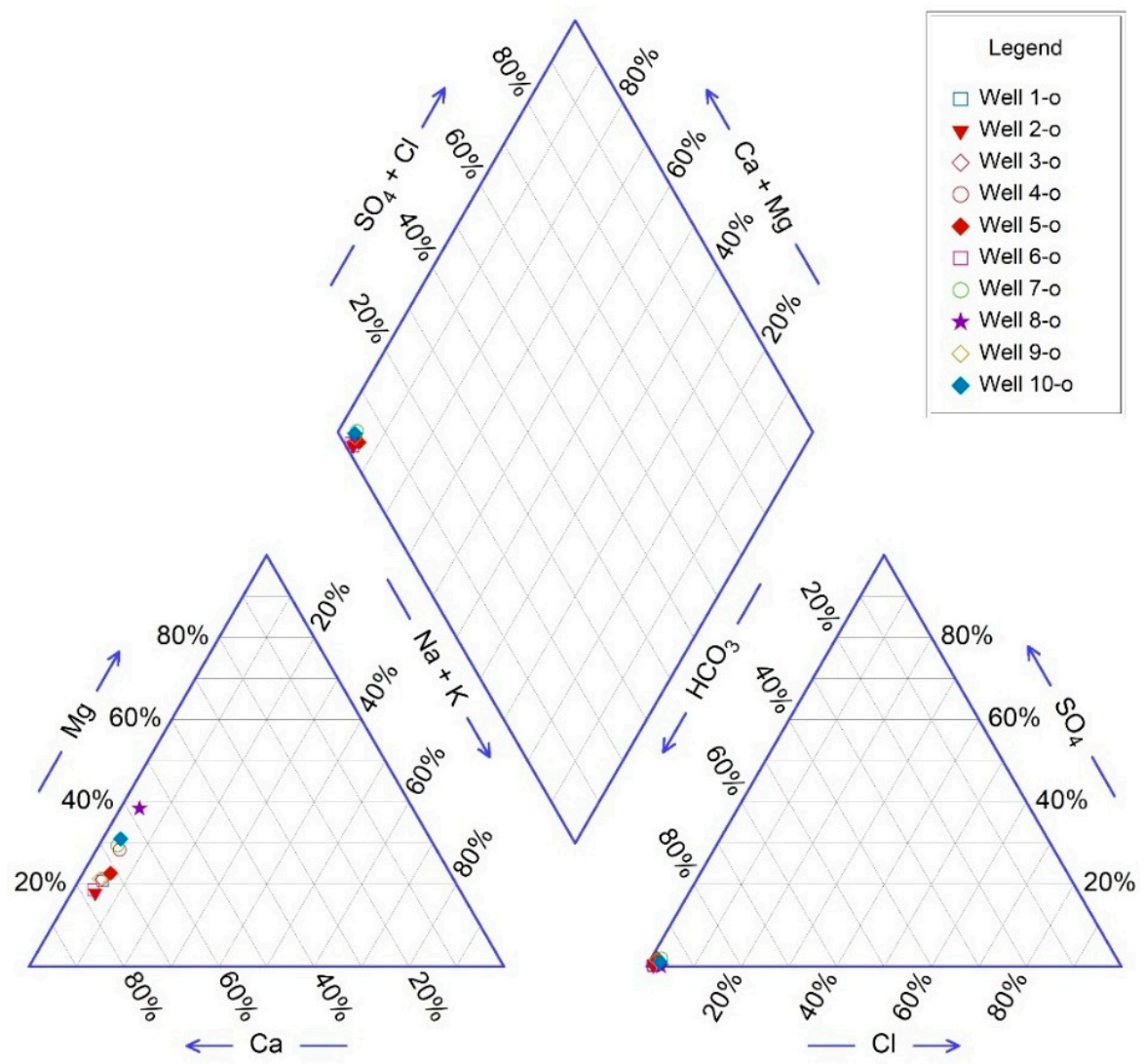

Figure 2. Piper diagram of test site groundwater chemical composition.

The average concentration of $\mathrm{TPH}$ in the groundwater near the remediation site reaches $5.8 \mathrm{mg} / \mathrm{L}$ (maximum $9.0 \mathrm{mg} / \mathrm{L}$ ) and depends on the season and local features. It is also important to note that according to previous studies, the maximum permissible concentration (MPC) of this contamination is exceeded here constantly. To prevent the distribution of pollution, environmental protection facilities were constructed, including a drainage system and collectors, to intercept the NAPL and pump it out. As a result, the main part of the pollution was successfully withdrawn, and discharging of NAPL into the river is not currently observed. However, there is persistent dissolved phase contamination that requires the implementation of additional measures. Bioremediation methods are considered to be efficient environmental measures and could accomplish additional groundwater treatment. It should be noted that petroleum hydrocarbon contamination in groundwater remains relevant; today, there are many similar cases in the oil industry around the world $[48,49]$, which prompts further research to solve this issue.

\section{Materials and Methods}

The implementation of the groundwater treatment was divided into several stages:

- Preparatory stage (field measurements and sampling);

- Project development for the installation of emitters and planning of treatment operations;

- Laboratory microbiological investigation;

- Preparation of a treatment system on the site (drilling of wells, installation of emitters and the necessary equipment) and implementation of groundwater remediation; 
- Monitoring of the processes of control over groundwater;

- Processing of the data received.

As part of the preparatory stage, an initial field survey of the site was carried out, and samples of groundwater were taken to determine the chemical composition and assess petroleum hydrocarbon contamination. The geological and soil property data were clarified and updated (the main initial characteristics of the study area are presented in Section 2). Moreover, samples of groundwater and soil were taken for laboratory microbiological investigation.

Hydrochemical and soil studies. Sampling of groundwater and soil was accomplished at 3 boreholes (inner diameter $60 \mathrm{~mm}$ ); water samples were taken from the river, and samples of NAPL and contaminated groundwater were gathered from the drainage system. At the same time, a field express analysis of water was carried out to determine the parameters of $\mathrm{pH}$, Eh, total dissolved solids (TDS), electrical conductivity, and temperature using an HI 98129 Combo water analyzer (HANNA Instruments, Nușfalău, Romania), an HI 98201 ORP meter (HANNA Instruments, Nușfalău, Romania), and a MARK-302M dissolved oxygen analyzer (Vzor, Nizhny Novgorod, Russia).

The water samples were assessed according to the following components and indicators: $\mathrm{HCO}_{3}{ }^{-}, \mathrm{CO}_{3}{ }^{2-}, \mathrm{SO}_{4}{ }^{2-}, \mathrm{Cl}^{-}, \mathrm{NO}_{3}{ }^{-}, \mathrm{NO}_{2}{ }^{-}, \mathrm{Ca}^{2+}, \mathrm{Mg}^{2+}, \mathrm{Na}^{+}, \mathrm{K}^{+}, \mathrm{NH}_{4}{ }^{+}$, total Fe, hardness, TDS, $\mathrm{pH}$, and total petroleum hydrocarbons (TPH). The following equipment was used: Kapel-104-T capillary electrophoresis system (Lumex, Saint-Petersburg, Russia), Expert-pH pH meter (Econix, Moscow, Russia), UNICO-1200 spectrophotometer (United Products and Instruments, Dayton, NJ, USA), Fluorat 02-3M liquid analyzer (Lumex, SaintPetersburg, Russia), and auxiliary equipment and devices. The mass concentration of TPH was determined by the fluorometric method on a Fluorat-02-3M liquid analyzer, and the extraction was performed with hexane.

Soil samples were tested to determine the properties of natural moisture, water saturation coefficient, soil density, porosity coefficient, particle size distribution (granulometric composition), and filtration coefficient. The granulometric composition of soils was determined by sieve and hydrometric methods in accordance with state standard 12536-2014 (soils: methods of laboratory granulometric (grain-size) and microaggregate distribution). Physical properties of soils (natural humidity, soil density, porosity, water saturation coefficient, and filtration coefficient) were determined in accordance with state standard 5180-2015 (soils: laboratory methods for determination of physical characteristics). Additionally, existing data about permeability properties determined in past field tests were included in the research.

Microbiological research. To isolate active cultures of aboriginal aerobic oil-oxidizing microorganisms, a water sample with sediment taken from the drainage system was used. The sample was kept for an hour, after which the precipitate was separated from the water by decantation into a sterile flask, then $100 \mathrm{~mL}$ of sterile $0.1 \%$ sodium pyrophosphate solution was added to the precipitate and it was sonicated on a SONOPULS device (Bandelin electronic Gmbh \& Co. KG, Berlin, Germany) at a frequency of $20 \mathrm{kHz}$ and a power of $70 \mathrm{~W}$ for $1 \mathrm{~min}$. The precipitate was settled for $2 \mathrm{~min}$ and the resulting solution was used for inoculation.

For this procedure, $0.3 \mathrm{~mL}$ samples of water and $0.3 \mathrm{~mL}$ samples of sediment solution were inoculated in Petri dishes with Raymond's medium for oil-oxidizing bacteria [50]. Inoculated dishes were incubated in oil vapor in a desiccator. The incubation was carried out in a thermostat at $28{ }^{\circ} \mathrm{C}$ for 2 weeks. The individual colonies of grown microorganisms, differing from each other in color, edge shape, or texture, were streaked onto new dishes with Raymond's medium and cultured in petroleum vapor in a thermostat at $28{ }^{\circ} \mathrm{C}$ for 2 weeks. A total of 5 cultures of oil-oxidizing microorganisms were obtained, 3 from a water sample and 2 from a sediment sample. The culture that showed the highest oil-oxidizing activity was used to obtain the biomass.

The growth of the biomass of the culture of oil-oxidizing microorganisms for treatment of the experimental site was carried out in a liquid medium composed of $10 \mathrm{~g} / \mathrm{L}$ glucose 
and $1.5 \mathrm{~g} / \mathrm{L}$ dry meat-peptone broth. Incubation was carried out for 3 weeks at room temperature and under aeration using an Atman At-A7500 compressor (Yangzhou Anipet Co., Yangzhou, China) at an air flow rate of $3 \mathrm{~L} / \mathrm{min}$. At the end of incubation, $20 \mathrm{~L}$ of liquid culture of oil-oxidizing microorganisms, containing $20 \mathrm{~g}$ of crude bacterial biomass, was obtained for treatment of the experimental site, and $2 \mathrm{~L}$ of culture were introduced into each treatment well.

It is known that the development of hydrocarbon-degrading microorganisms is influenced by the availability of nitrogen and phosphorus sources [6]. Yaniga et al. (1985) showed that the addition of nitrogen- and phosphorus-containing substances to the aquifer favorably affects the life of hydrocarbon-oxidizing bacteria and increases their number up to 1000 times, while maintaining the concentration of water-dissolved oxygen at a level of 5-10 mg/L [51]. Therefore, an additional $20 \mathrm{~L}$ of solution containing $\mathrm{NH}_{4} \mathrm{Cl}$ and $\mathrm{KH}_{2} \mathrm{PO}_{4}$ (330 and $44 \mathrm{~g} / \mathrm{L}$, respectively) was prepared, and $2 \mathrm{~L}$ of solution was introduced into each treatment well. It should be noted that the polymer material in the emitters used for saturating the groundwater with oxygen is very poorly permeable to substances that form ions in solution [52]; therefore, the liquid culture of oil-oxidizing microorganisms and the solution of nitrogen- and phosphorus-containing substances was introduced into the wells directly, and not through the diffusion tubes of the emitters.

Construction of the field trail site. The emitters determined the parameters of well construction in this project (Figure 3). These devices were designed to disperse various substances through permeable tubular materials. In this test we used Waterloo emitters (Solinst, Georgetown, ON, Canada).

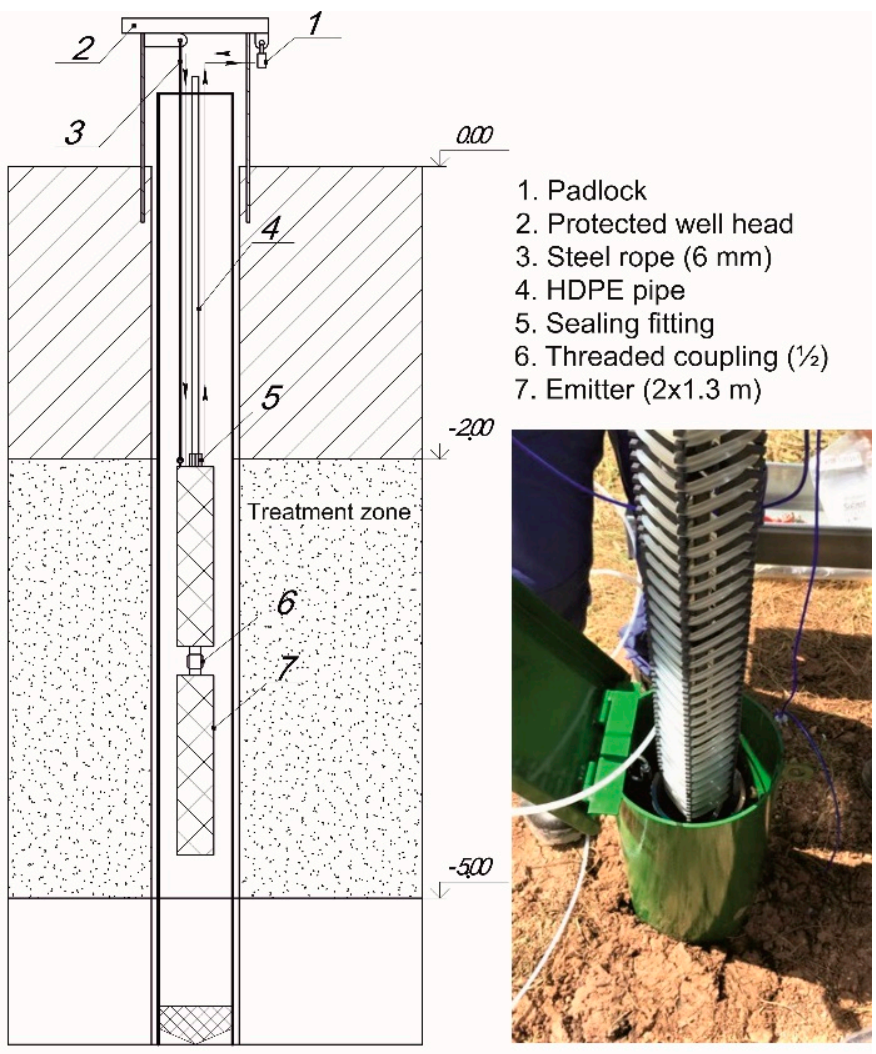

Figure 3. Construction of treatment well with emitter.

Emitters were installed in the treatment wells to supply oxygen to the underground space. A central tube (14 $\mathrm{mm}$ in diameter) was used for the dosed supply of oil-oxidizing cultures of microorganisms and reagents, as well as sampling. Taking into account the hydrological regime of the territory, the thickness of the aquifer, possible changes in groundwater levels, and the recommendations of the manufacturer, emitters with an 
appropriate diameter, $95.6 \mathrm{~mm}$, and a length of $2.6 \mathrm{~m}$ (assembled from two $1.3 \mathrm{~m}$ units) were used in the project. The diameter of pipes for the well casing was $125 \mathrm{~mm}$, and the material of the diffusion tube was silicone. The depth of the wells (about $5.3 \mathrm{~m}$ ) was determined by the parameters of the saturated zone and the groundwater level. The casing is a single system of unplasticized polyvinyl chloride (PVC-U), including a conductor, lowered to a depth of $2 \mathrm{~m}$ to cover the upper free-flowing horizons, with a filter column installed over the entire thickness of the aquifer for effective groundwater treatment.

The front of the treatment area presented a row of 10 wells (Figure 4a), with an interval of about $2 \mathrm{~m}$ between them, located almost perpendicular to the direction of the groundwater flow (Figure $4 \mathrm{~b}$ ).
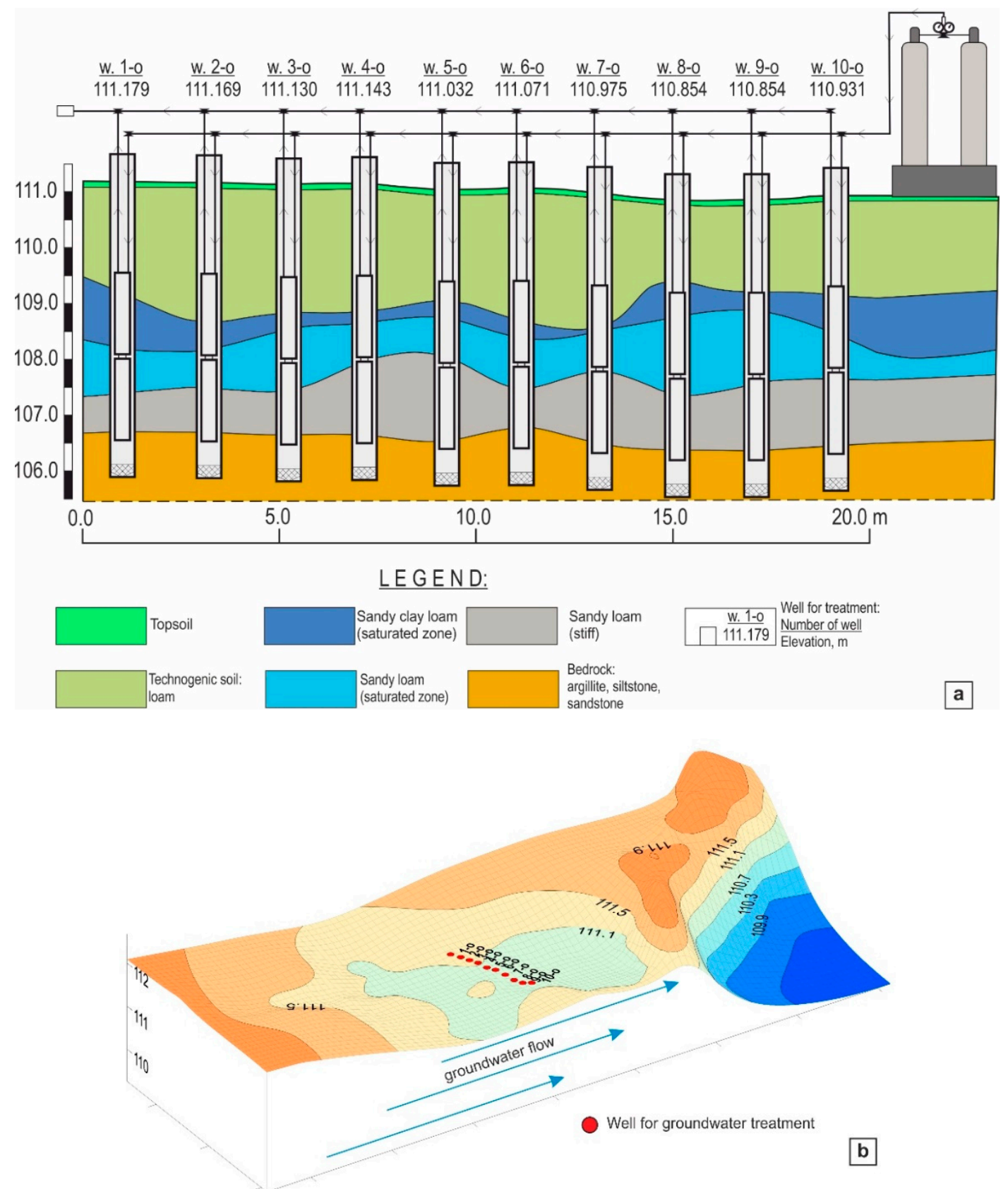

Figure 4. (a) Geological cross-section and (b) scheme of treatment wells system location. 
The wells were connected with an oxygen supply mainline, and the mainline and wells with emitters installed inside were connected with PVC pipe, using stop valves. At the final stage of system assembly, a test run of oxygen was carried out to check the tightness.

Treatment of contaminated water using emitters. Degradation of petroleum hydrocarbons in the environment occurs under both aerobic and anaerobic conditions. However, the destruction under aerobic conditions is much faster; therefore, it is preferable to use oxygen as an oxidizing agent [24]. At the same time, although physicochemical processes play a significant role in the self-cleaning of biocenoses from oil and oil products, complete destruction of oil hydrocarbons is possible only with the participation of hydrocarbonoxidizing bacteria [13]. Since oxygen is consumed during the oxidation of petroleum hydrocarbons, its concentration must be maintained at the level required for the survival of hydrocarbon-oxidizing bacteria. Yaniga et al. (1985) showed that the concentration of dissolved oxygen in groundwater should be maintained at a level of at least 5-10 mg/L for the degradation of petroleum hydrocarbons [50]. In this regard, the main criterion for monitoring during the work was to maintain the oxygen concentration in the water not lower than the optimal level.

Groundwater monitoring and efficiency of treatment. Groundwater monitoring aimed at assessing the treatment rate and general observations of the situation in the study area were among the main parts of the project.

The basic controlled parameters were changes in the concentrations of dissolved oxygen (DO) and total petroleum hydrocarbons (TPH). Taking into account a relatively widespread approach to assessing the effectiveness of bioremediation [53], the rate of groundwater treatment was determined according to the TPH content. We also used this parameter because the TPH is most often used by national MPC standards and regulatory authorities to assess petroleum hydrocarbon contamination. Additionally, during each stage of monitoring, the following parameters were determined: TDS, $\mathrm{pH}$, temperature, electrical conductivity, and groundwater level.

Assessment of groundwater treatment efficiency was conducted after 30, 45, 60, 75, and 90 days of treatment. To obtain the initial data, water samples were taken from the study area and analyzed according to the given parameters before the start of groundwater treatment.

\section{Results and Discussion}

The observation data of the main parameters of groundwater made it possible to identify the following patterns in the study area. TDS, which characterizes the total content of dissolved particles in water, changed insignificantly during the experiment and averaged 593.9-765.0 ppm, so the water at the test site was classified as fresh, which is typical for a treated aquifer. The $\mathrm{pH}$ of the water remained practically unchanged throughout the experiment and averaged 6.57-7.02, which made it possible to determine the water as neutral. The measurement results are presented in Table 1.

Table 1. Results of field measurements of groundwater parameters.

\begin{tabular}{|c|c|c|c|c|c|c|c|c|c|c|c|}
\hline Date & Parameter & $\begin{array}{c}\text { Well } \\
\text { 1-o }\end{array}$ & $\begin{array}{c}\text { Well } \\
2-0\end{array}$ & $\begin{array}{c}\text { Well } \\
\text { 3-o }\end{array}$ & $\begin{array}{c}\text { Well } \\
\text { 4-o }\end{array}$ & $\begin{array}{c}\text { Well } \\
5-0\end{array}$ & $\begin{array}{c}\text { Well } \\
6-0\end{array}$ & $\begin{array}{c}\text { Well } \\
\text { 7-o }\end{array}$ & $\begin{array}{c}\text { Well } \\
8-0\end{array}$ & $\begin{array}{c}\text { Well } \\
9-0\end{array}$ & $\begin{array}{l}\text { Well } \\
10-0\end{array}$ \\
\hline \multirow{3}{*}{$05 / 28 / 20$} & TDS (ppm) & 847 & 765 & 735 & 608 & 591 & 680 & 610 & 627 & 563 & 615 \\
\hline & $\begin{array}{l}\text { Conductivity } \\
(\mu \mathrm{S} / \mathrm{cm})\end{array}$ & 1734 & 1487 & 1470 & 1240 & 1185 & 1355 & 1225 & 1253 & 1121 & 1212 \\
\hline & $\mathrm{pH}$ & 6.48 & 6.92 & 6.75 & 6.42 & 6.70 & 6.73 & 6.93 & 6.81 & 6.82 & 6.78 \\
\hline
\end{tabular}


Table 1. Cont.

\begin{tabular}{|c|c|c|c|c|c|c|c|c|c|c|c|}
\hline Date & Parameter & $\begin{array}{c}\text { Well } \\
\text { 1-o }\end{array}$ & $\begin{array}{c}\text { Well } \\
\text { 2-o }\end{array}$ & $\begin{array}{c}\text { Well } \\
\text { 3-o }\end{array}$ & $\begin{array}{c}\text { Well } \\
\text { 4-o }\end{array}$ & $\begin{array}{c}\text { Well } \\
5-0\end{array}$ & $\begin{array}{c}\text { Well } \\
\text { 6-o }\end{array}$ & $\begin{array}{c}\text { Well } \\
7-0\end{array}$ & $\begin{array}{c}\text { Well } \\
\text { 8-o }\end{array}$ & $\begin{array}{c}\text { Well } \\
9-0\end{array}$ & $\begin{array}{l}\text { Well } \\
10-0\end{array}$ \\
\hline \multirow{3}{*}{$06 / 30 / 20$} & \multirow{3}{*}{$\begin{array}{c}\text { TDS (ppm) } \\
\text { Conductivity } \\
(\mu S / \mathrm{cm}) \\
\mathrm{pH}\end{array}$} & 966 & 697 & 595 & 590 & 593 & 577 & 634 & 624 & 622 & 565 \\
\hline & & 1933 & 1394 & 1190 & 1184 & 1181 & 1154 & 1272 & 1248 & 1243 & 1167 \\
\hline & & 6.73 & 6.96 & 6.94 & 6.97 & 6.85 & 6.87 & 7.01 & 6.99 & 6.93 & 7.01 \\
\hline \multirow{3}{*}{$07 / 15 / 20$} & \multirow{3}{*}{$\begin{array}{c}\text { TDS (ppm) } \\
\text { Conductivity } \\
(\mu S / \mathrm{cm}) \\
\mathrm{pH}\end{array}$} & 933 & 623 & 584 & 589 & 585 & 643 & 597 & 598 & 590 & 603 \\
\hline & & 1800 & 1252 & 1166 & 1183 & 1170 & 1285 & 1190 & 1198 & 1180 & 1208 \\
\hline & & 6.78 & 7.22 & 6.86 & 6.85 & 6.82 & 6.88 & 6.90 & 6.85 & 6.85 & 7.12 \\
\hline \multirow{3}{*}{$07 / 30 / 20$} & \multirow{3}{*}{$\begin{array}{c}\text { TDS (ppm) } \\
\text { Conductivity } \\
(\mu S / \mathrm{cm}) \\
\mathrm{pH}\end{array}$} & 931 & 571 & 574 & 583 & 577 & 625 & 610 & 601 & 590 & 624 \\
\hline & & 1851 & 1146 & 1159 & 1183 & 1160 & 1241 & 1198 & 1215 & 1163 & 1238 \\
\hline & & 6.79 & 7.15 & 7.10 & 7.00 & 6.95 & 6.88 & 7.11 & 7.00 & 7.09 & 7.20 \\
\hline \multirow{3}{*}{$08 / 13 / 20$} & \multirow{3}{*}{$\begin{array}{l}\text { TDS (ppm) } \\
\text { Conductivity } \\
(\mu S / \mathrm{cm}) \\
\mathrm{pH}\end{array}$} & 902 & 587 & 581 & 590 & 582 & 621 & 595 & 594 & 592 & 630 \\
\hline & & 1797 & 1171 & 1168 & 1177 & 1165 & 1240 & 1192 & 1226 & 1185 & 1259 \\
\hline & & 6.77 & 7.06 & 7.05 & 6.92 & 6.89 & 6.90 & 6.97 & 7.09 & 6.99 & 7.10 \\
\hline \multirow{3}{*}{$08 / 28 / 20$} & \multirow{3}{*}{$\begin{array}{c}\text { TDS (ppm) } \\
\text { Conductivity } \\
(\mu S / \mathrm{cm}) \\
\text { pH }\end{array}$} & 584 & 595 & 584 & 581 & 593 & 611 & 591 & 603 & 595 & 637 \\
\hline & & 1175 & 1195 & 1166 & 1175 & 1168 & 1225 & 1173 & 1192 & 1168 & 1272 \\
\hline & & 6.67 & 6.82 & 6.84 & 6.80 & 7.01 & 7.03 & 7.07 & 7.01 & 7.09 & 6.99 \\
\hline
\end{tabular}

The groundwater temperature averaged $+7.46{ }^{\circ} \mathrm{C}$ with a tendency to increase caused by seasonal changes and an insignificant general anthropogenic impact of an industrial site. The groundwater level gradually decreased (by an average of $0.41 \mathrm{~m}$ ), which was caused by the natural hydrological regime in the summer in this region.

Oxygen saturation and DO content. Oxygen saturation and DO content are among the key parameters of the water used to assess the operation of the emitter system as a whole. It has been noted that the total flux of supplied oxygen must meet or exceed the total flux of oxygen demand imposed by the pollutant's plume [54]. In the case of groundwater pollution in BTEX, every $1 \mathrm{~g}$ decrease in BTEX uses $3 \mathrm{~g}$ of oxygen, assuming complete mineralization of BTEX. "Excess" dissolved oxygen presumably would be available for further degradation of BTEX downgradient [41,55].

Based on previous experience, it was found that in order to obtain reliable data on the oxygen content and saturation of water, it is recommended to measure these parameters directly in the field to avoid possible data distortion when taking and transporting water samples. The changes of DO in the groundwater during the study are shown in Figure 5.

Initially, the average DO concentration in the research area varied from 1.0 to $2.0 \mathrm{mg} / \mathrm{L}$. After the installation of the emitter system and the beginning of oxygen delivery, the average DO concentration increased significantly, with a maximum value of about $45 \mathrm{mg} / \mathrm{L}$. The maximum average DO concentration was $39.2 \mathrm{mg} / \mathrm{L}$, while the oxygen saturation reached $321.5 \%$. This amount of DO mostly exceeded the demand for DO to TPH oxidation in wells: the average TPH content was $4.33 \mathrm{mg} / \mathrm{L}$, and demands in DO were about $13 \mathrm{mg} / \mathrm{L}$. Accordingly, excess DO (about $26 \mathrm{mg} / \mathrm{L}$ ) could be available for further TPH degradation downgradient of the treatment wells. Periods of decreasing and stabilizing oxygen concentrations were identified, which could be caused by environmental temperature changes, dilution of water by atmospheric precipitation, or the technological process of oxygen delivery through the emitter system. Additionally, one of the factors affecting the supply of oxygen to groundwater could be the formation of a film on the surface of the emitters (Figure 6), which prevents oxygen diffusion. 


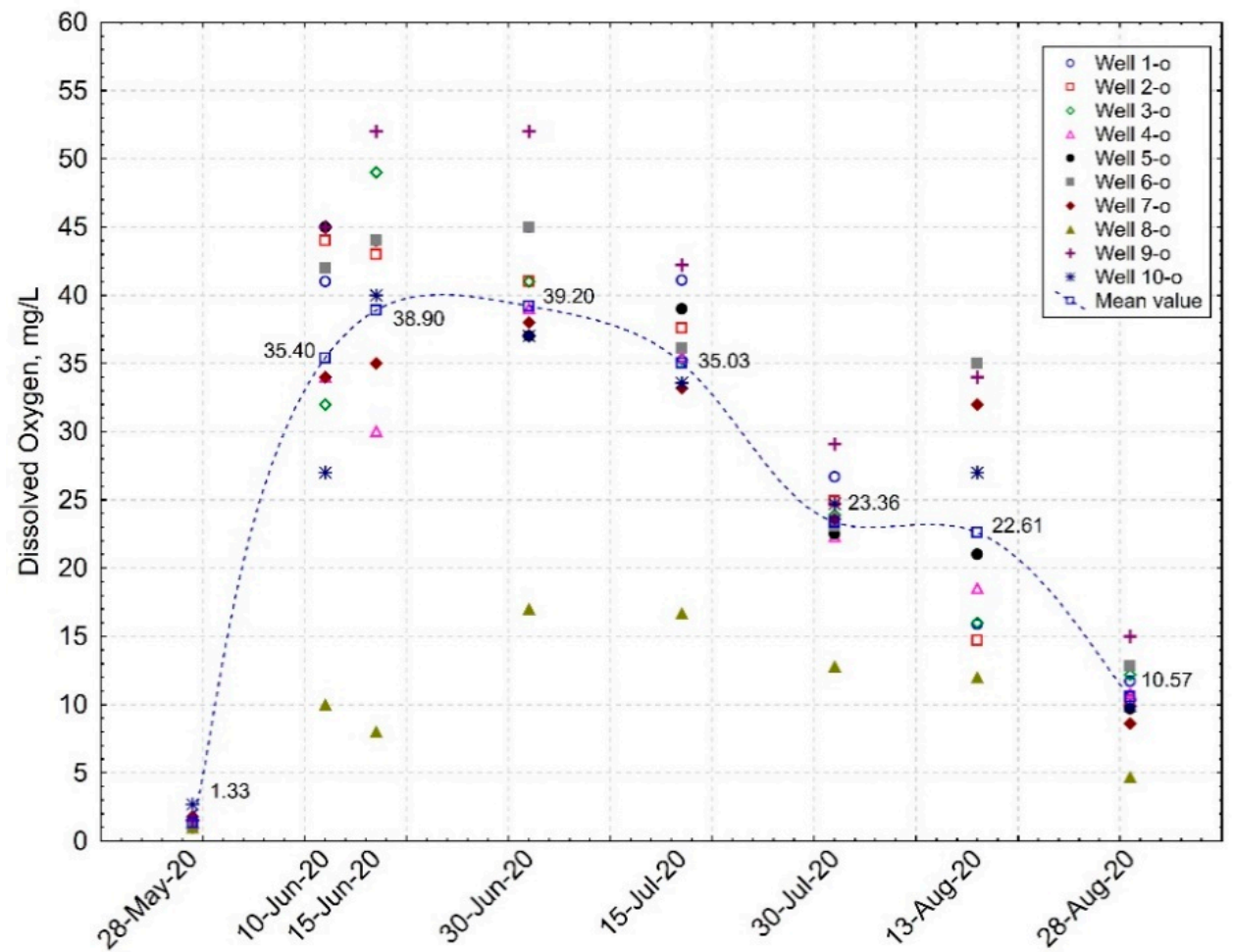

Figure 5. Dissolved oxygen content in treatment wells during field trial test.
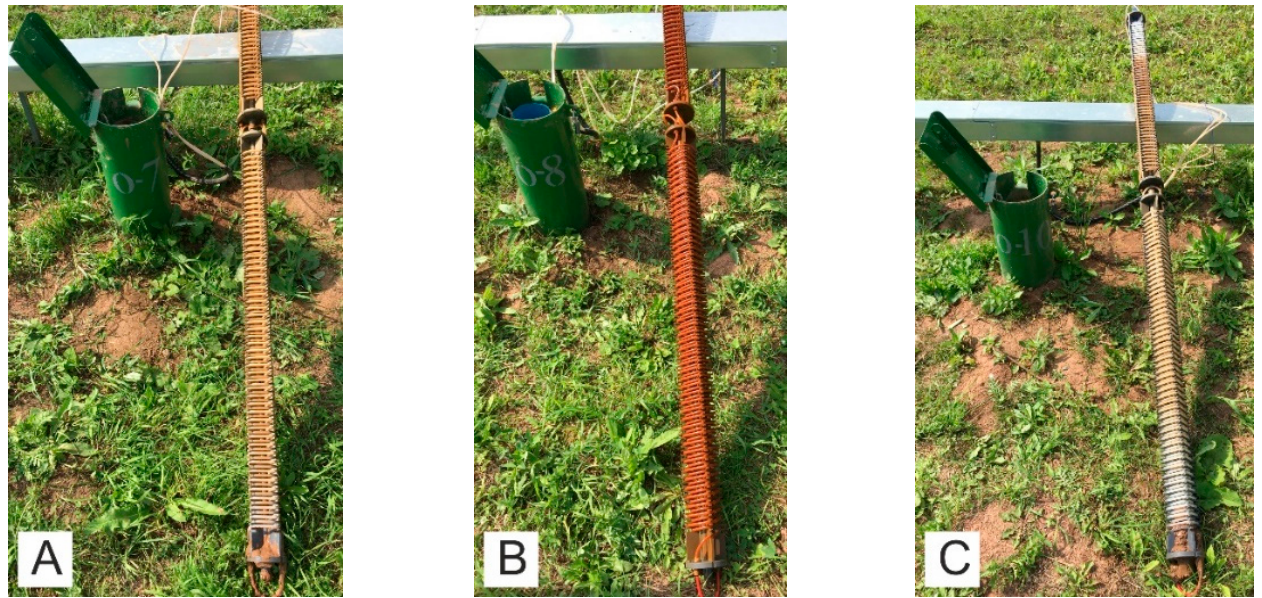

Figure 6. Newly formed film on emitter tubes during oxygen delivery operation: (A) well 7-o; (B) well 8-o; and (C) well 10-o.

Figure 6 shows the emitters after 90 days of use. Visually, the most intense film was formed on the surface of the emitter tube from well 8-o compared with wells 7-o and 10-o. At the same time, the minimum DO values were found in well 8-o (as shown in Figure 5), which could be due to the local features of the composition of water and soil caused by anthropogenic influence in certain areas.

To clarify the composition and distribution of the newly formed film, detailed mineralogical studies were conducted, including microprobe analysis and analysis of the sediment by scanning electron microscopy (JEOL, Tokyo, Japan). The picture at low magnification $(\times 300)$ clearly shows that the sediment was distributed unevenly on the surface of the tube, while some areas were not covered with plaque at all. The plaque contained individual grains and aggregates up to $50 \mu \mathrm{m}$ in size (Figure 7a). The section of the tube surface covered with a solid crust was divided by microcracks (width about $1 \mu \mathrm{m}$ ). The size 
of the predominant mass of particles was less than 5 microns, i.e., these particles belonged to the clay fraction. A large part of the tube surface was covered by aggregates of these particles. There were voids (such as pores) up to 10 microns in size between the particles and their aggregates. The pipe from well 7-o had film with lower visual density, and certain sections were practically free of these particles (Figure $7 \mathrm{~b}$ ).
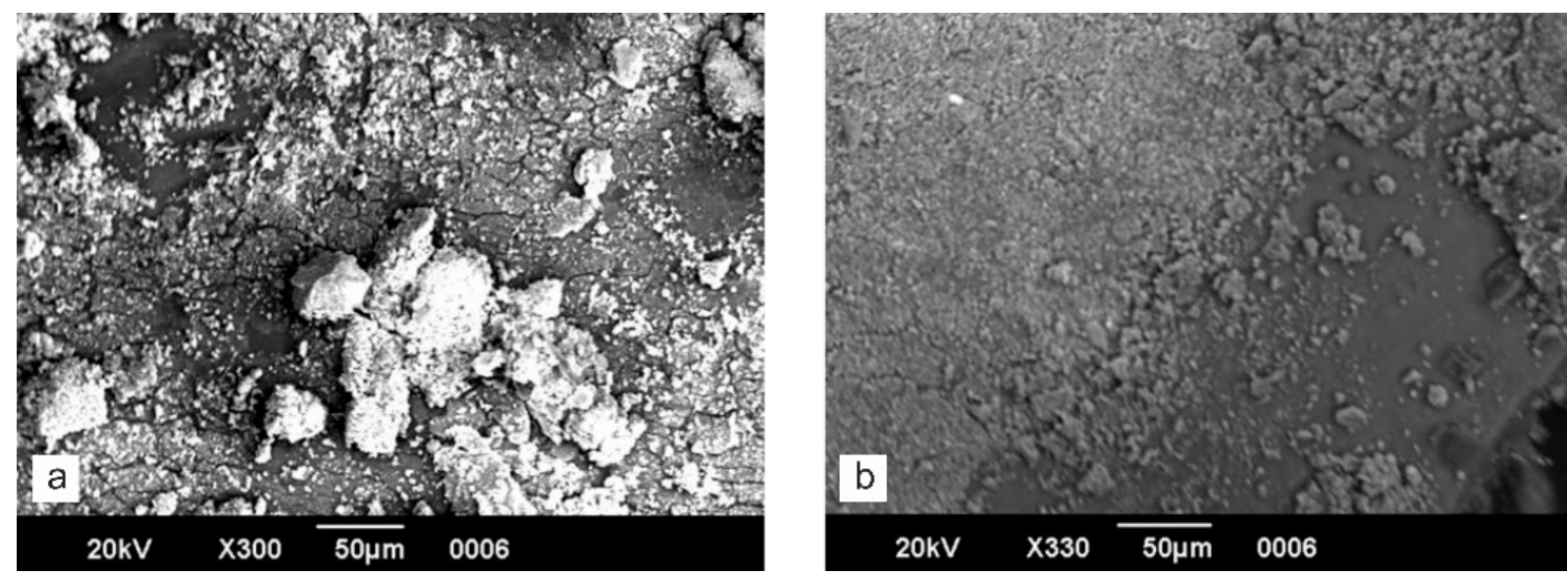

Figure 7. SEM images of pipe surface from (a) well 8-o and (b) well 7-o.

The chemical composition of films from the surface of pipes, determined by the microprobe method using an INCA Energy 350 energy dispersive spectrometer (Oxford Instruments, Oxford, U.K.), is characterized predominantly by silica and alumina (76-92\% of total content). Oxides of iron, magnesium, and calcium are present in variable but subordinate amounts. Alkali metal oxides are noted in small amounts. The constant presence of phosphorus and chlorine compounds is typical, probably caused by the biomass and nutrients added for microorganisms.

In general, the monitoring data allow us to conclude that throughout the field test, groundwater was saturated with oxygen, and its concentration was maintained at the required level. The average content of dissolved oxygen in groundwater in the treatment zone during the test was $28.55 \mathrm{mg} / \mathrm{L}$, indicating that the system was operating properly during the testing of the groundwater treatment complex.

The content of total petroleum hydrocarbons (TPH) in groundwater in the treatment zone is also one of the main parameters describing the operation of the system. In the monitoring framework, prior to the start of bioremediation, groundwater sampling of the study area was carried out. Initial sampling (28 May 2020) was carried out within the minimum possible time from the start of system operation in order to obtain reliable initial values. According to the results of the initial sampling, the average content of $\mathrm{TPH}$ for the site was $4.33 \mathrm{mg} / \mathrm{L}$, and this amount required about $13 \mathrm{mg} / \mathrm{L}$ DO to be completely degraded.

Subsequently, samples for analysis were taken from the wells according to the monitoring plan (described above). A decrease in TPH in the treatment zone began to be revealed in the first 30 days (Figure 8) of implementation of the cleaning system, with a general trend toward a decreased concentration of the contaminant. 


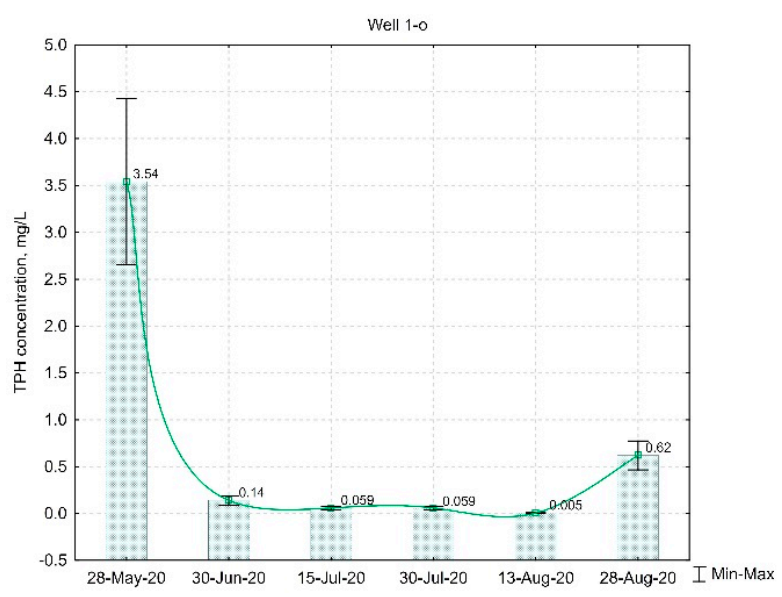

(a)

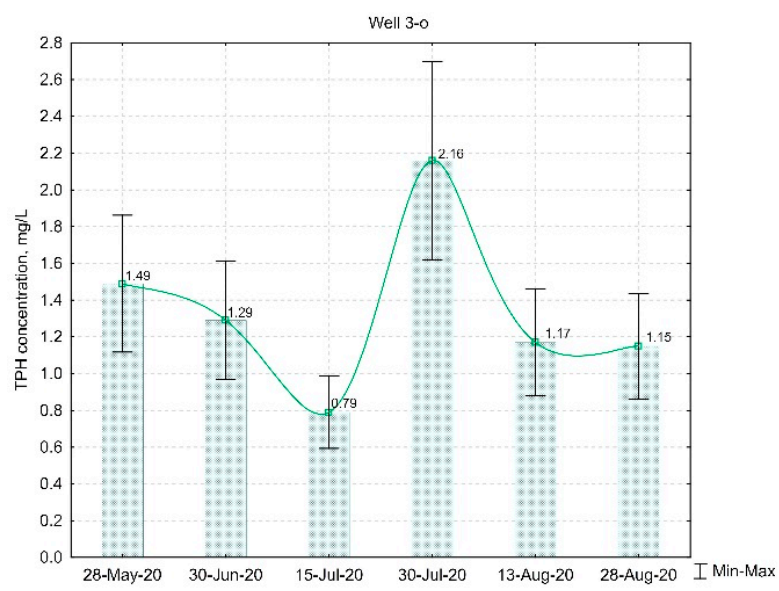

(c)

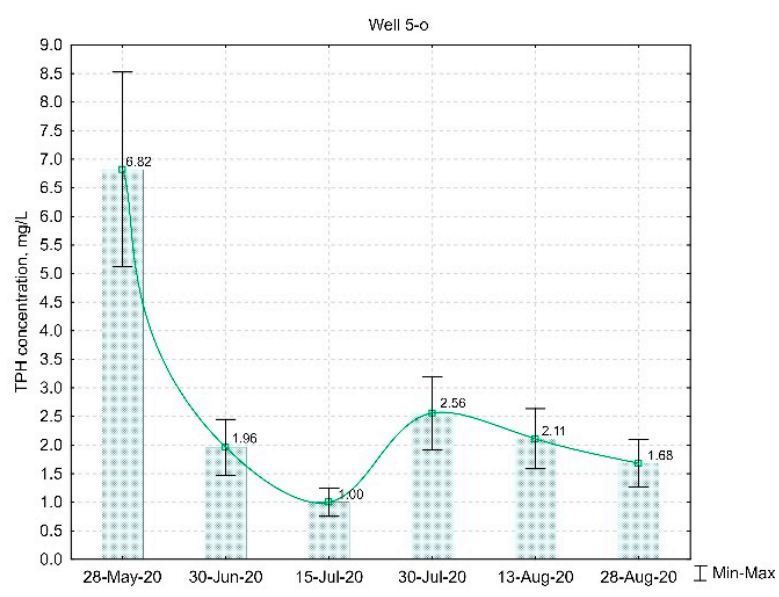

(e)

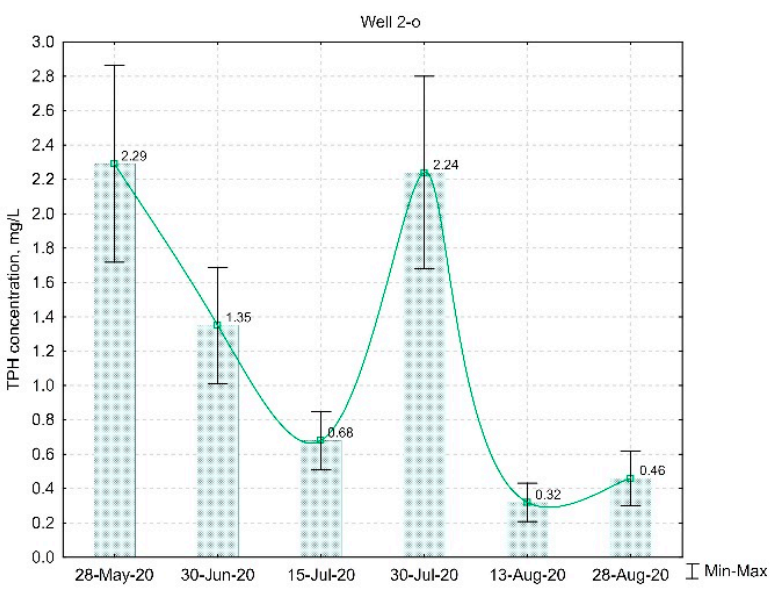

(b)

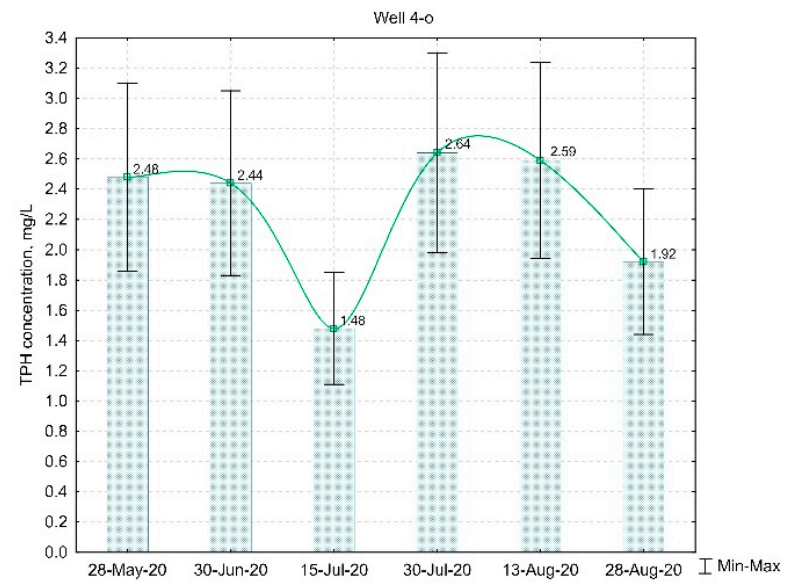

(d)

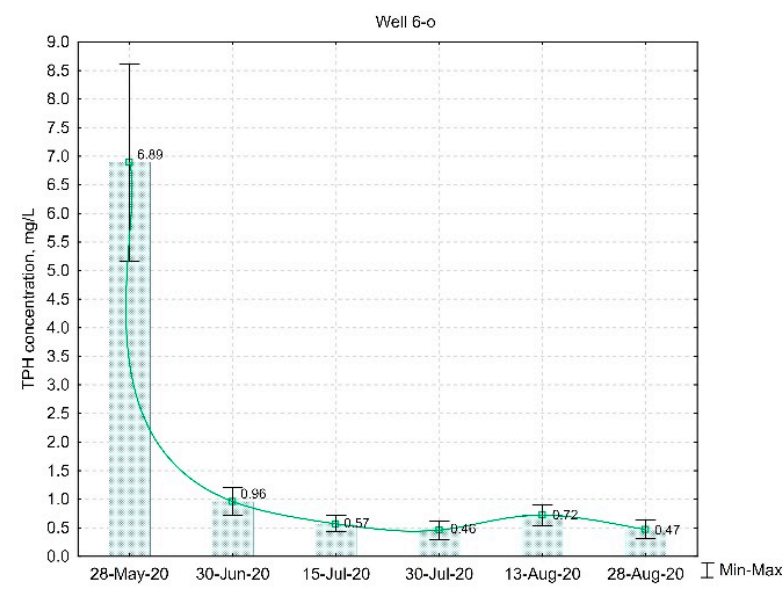

(f)

Figure 8. Cont. 


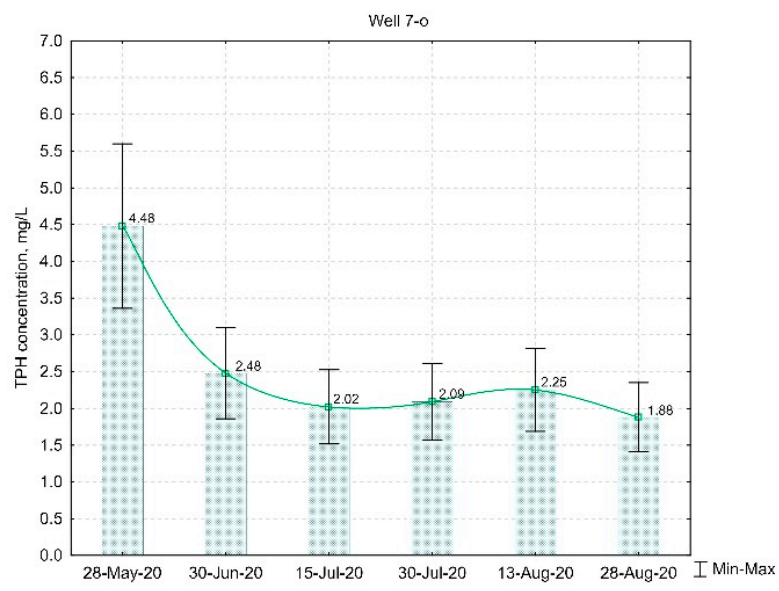

(g)

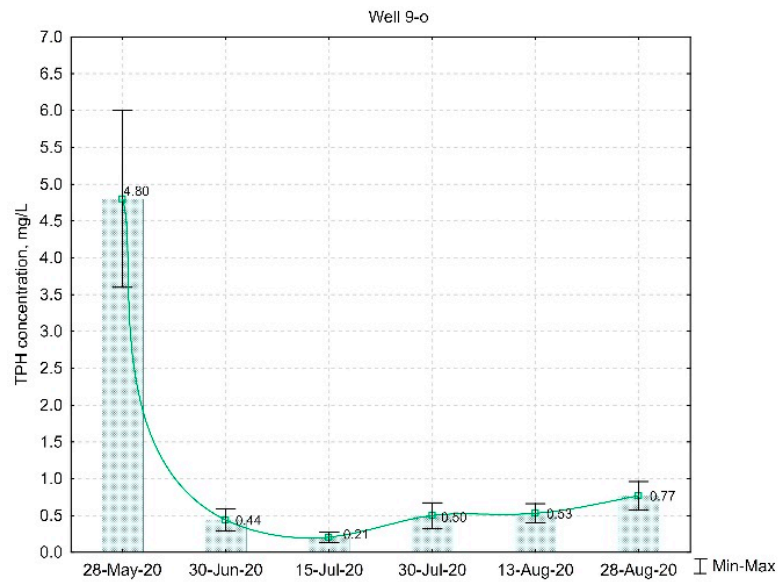

(i)

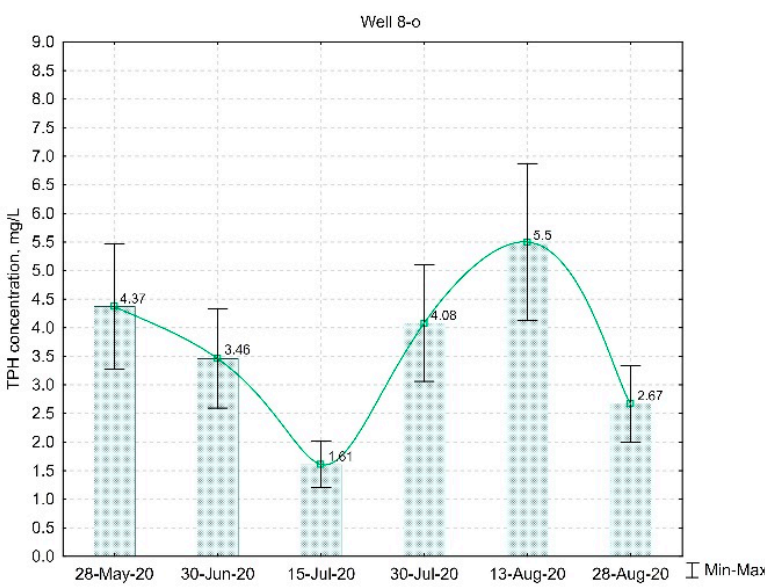

(h)

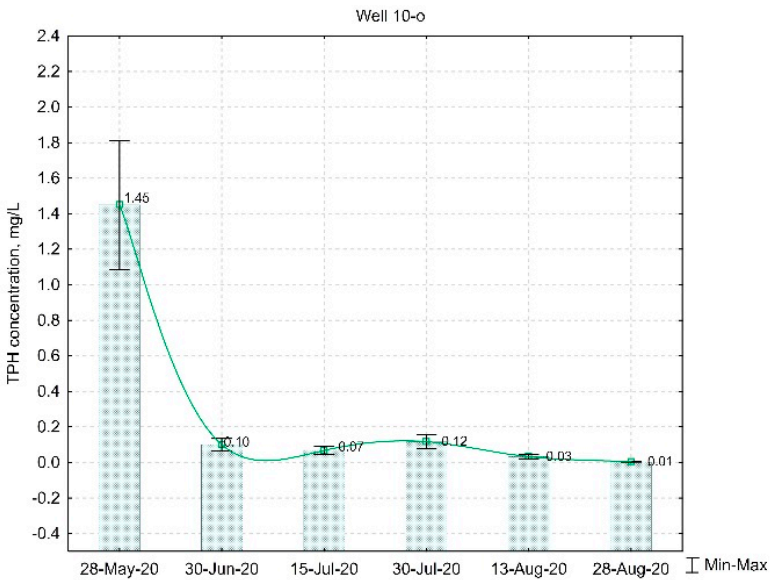

(j)

Figure 8. Total petroleum hydrocarbon concentration in groundwater during field test (well 1-(a); well 2-(b); well 3-(c); well 4-(d); well 5-(e); well 6-(f); well 7-(g); well 8-(h); well 9-(i); and well 10-(j)).

A relatively distinctive minimum of average TPH concentration $(0.84 \mathrm{mg} / \mathrm{L}$; average rate of purification $79.3 \%$ ) was observed at the 47 th day (sampling on 15 July 2020) after starting the operation. We suppose it was probably caused by the most intense phase of the vital activity of the introduced biomass. The subsequent increase in TPH content could have been caused by the influx of a new substance of hydrocarbons from a permanent source of pollution, while infiltration from atmospheric precipitation or from soils with significant residual oil saturation occurred. At the end of the treatment (28 August), the DO concentration in the treatment wells exceeded the demand for DO to complete TPH degradation, except for in well 8-o (Table 2). Therefore, the remediation of groundwater could be continued downgradient from outside the wells.

However, based on the obtained data, it is clear that the treatment system is potentially able to cope with the inputs of new contaminants. It is worth noting that the tendency of decreasing content of pollutants in the treatment zone continued throughout the test, and the revealed features, in general, may be typical for most real objects where a pollution source has been formed and a persistent contaminated flow is observed at the site. The fact that the system continued to operate effectively in such conditions is its clear advantage. 
Table 2. Groundwater parameters at final stage of treatment system testing (28 August).

\begin{tabular}{ccccc}
\hline Well & $\begin{array}{c}\text { TPH } \\
(\mathbf{m g} / \mathbf{L})\end{array}$ & $\begin{array}{c}\text { DO } \\
(\mathbf{m g} / \mathbf{L})\end{array}$ & $\begin{array}{c}\text { Demand for DO } \\
(\mathbf{m g} / \mathbf{L})\end{array}$ & $\begin{array}{c}\text { Excess DO } \\
(\mathbf{m g} / \mathrm{L})\end{array}$ \\
\hline $1-\mathrm{o}$ & 0.62 & 11.7 & 1.86 & 9.84 \\
$2-\mathrm{o}$ & 0.46 & 10.3 & 1.38 & 8.92 \\
$3-\mathrm{O}$ & 1.15 & 12.2 & 3.45 & 8.75 \\
$4-\mathrm{o}$ & 1.92 & 10.8 & 5.76 & 5.04 \\
$5-\mathrm{o}$ & 1.68 & 9.7 & 5.04 & 4.66 \\
$6-\mathrm{o}$ & 0.47 & 12.8 & 1.41 & 11.39 \\
$7-\mathrm{o}$ & 1.88 & 8.6 & 5.64 & 2.96 \\
$8-\mathrm{O}$ & 2.67 & 4.7 & 8.01 & -3.31 \\
9-o & 0.77 & 15 & 2.31 & 12.69 \\
$10-\mathrm{o}$ & 0.01 & 9.9 & 0.03 & 9.87 \\
\hline
\end{tabular}

At the final stage of testing (day 90), the rate of cleaning (reduction in TPH) was estimated similar to the method in [55]. The average concentration of TPH in the treatment zone was $1.16 \mathrm{mg} / \mathrm{L}$, i.e., the reduction in $\mathrm{TPH}$ after treatment was $73.1 \%$. In addition, it was demonstrated that decreased hydrocarbon pollution during TPH biostimulation and bioaugmentation was accompanied by reduced toxicity as well as genotoxicity $[56,57]$. During the technology testing period, the highest reduction was noted in well 10-o, where it was $95.5 \%$, with a maximum of $99.7 \%$ noted at the final stage (Table 3). This could be due to the favorable location of well 10-o relative to the entire treatment system and groundwater flow. For the studied area, certain zones (wells 3-o, 4-o, and 8-o) with reduced treatment rates were also found, which may have been caused by irregular distribution of contaminants and micro-local technogenic (or natural) features of the area.

Table 3. Efficiency estimates of groundwater treatment in relation to initial TPH concentrations.

\begin{tabular}{ccccccccccc}
\hline \multirow{2}{*}{ Date } & \multicolumn{7}{c}{ Efficiency of Groundwater Treatment ${ }^{\mathbf{c}}$} \\
\cline { 2 - 11 } & Well 1-o & Well 2-o & Well 3-o & Well 4-o & Well 5-o & Well 6-o & Well 7-o & Well 8-o & Well 9-o & Well 10-o \\
\hline $05 / 28 / 20$ & 0.000 & 0.000 & 0.000 & 0.000 & 0.000 & 0.000 & 0.000 & 0.000 & 0.000 & 0.000 \\
$06 / 30 / 20$ & 0.960 & 0.410 & 0.134 & 0.016 & 0.713 & 0.861 & 0.446 & 0.208 & 0.908 & 0.931 \\
$07 / 15 / 20$ & 0.983 & 0.703 & 0.470 & 0.403 & 0.853 & 0.917 & 0.549 & 0.632 & 0.957 & 0.953 \\
$06 / 30 / 20$ & 0.983 & 0.022 & 0.000 & 0.000 & 0.625 & 0.933 & 0.533 & 0.066 & 0.896 & 0.919 \\
$08 / 13 / 20$ & 0.999 & 0.860 & 0.215 & 0.000 & 0.691 & 0.896 & 0.498 & 0.000 & 0.890 & 0.977 \\
$08 / 28 / 20$ & 0.825 & 0.799 & 0.228 & 0.226 & 0.754 & 0.932 & 0.580 & 0.389 & 0.840 & 0.997 \\
\hline
\end{tabular}

${ }^{1}$ Groundwater treatment efficiency is evaluated from 0 to 1 , where 0 is initial TPH concentration and 1 is complete cleaning of contaminant relative to initial concentration (i.e., absence of TPH in water or concentration below detection limit).

A statistical analysis of the obtained data was done by Statistica 7.0 software (StatSoft Inc., Tulsa, OK, USA). We used the data on TPH and DO content in the treatment wells obtained during treatment. A statistically significant low to moderate negative correlation between TPH and DO content was revealed (Spearman's R $=-0.47, p<0.001$ ), so we suppose this effect reflects oxidation of TPH with DO. Predominantly more TPH was oxidized, and subsequently, more DO was considered as "excess".

Microbial activity in hydrocarbon-polluted groundwater is considered a dominant process capable of reducing pollution $[13,21,28]$. Bioaugmentation of polluted sites, based on re-inoculation of indigenous microorganisms previously enriched under laboratory conditions, enhances microbial activity, thus improving the degradation of hydrocarbons [58]. The addition of indigenous hydrocarbon-oxidizing microorganisms, enriched under laboratory conditions and with the most degradative activity, was used in our study. Crude bacterial biomass of $2 \mathrm{~g}$ wet weight was introduced into each treatment well. It was demonstrated that successful bioremediation of hydrocarbon-polluted groundwater is reached when biostimulation by the addition of appropriate nutrients (nitrogen and/or phospho- 
rus) results in improved metabolic activity of indigenous microorganisms [6]. We added nitrogen as $\mathrm{NH}_{4} \mathrm{Cl}$ and phosphorus as $\mathrm{KH}_{2} \mathrm{PO}_{4}$, in amounts of $660 \mathrm{~g}$ and $88 \mathrm{~g}$, respectively, into each treatment well to stimulate both amended cultures of hydrocarbon-oxidizing microorganisms and the same microorganisms inhabiting the groundwater. The added amounts of nitrogen and phosphorus did not affect the eutrophication of the receiving stream and were not toxic to microorganisms, as they were diluted 100 times immediately after being added the groundwater, and in total 1000 times until arriving at the stream.

Microbial activity in groundwater requires specific conditions, such as the presence of electron acceptors [59]. Groundwater is generally devoid of oxygen due to the utilization of oxygen by aerobic microorganisms, including hydrocarbon-oxidizing ones. Therefore, remediation techniques require supplying oxygen to polluted groundwater [1]. We used Waterloo emitters, which provide uniform concentrations of dissolved oxygen in groundwater over long periods of time, which may encourage more efficient in situ remediation, as supposed in another study [52]. Another advantage of using emitters is the absence of bubbling, which prevents significant stripping of volatile compounds from the treatment wells [55]. According to the study results, overall, the operation of the system was generally assessed as sufficiently effective and could be used for further treatment.

\section{Conclusions}

This study shows that in situ biodegradation of TPH using biostimulation (with oxygen added as a stimulant) and bioaugmentation methods in areas with loam and sandy loam soils could significantly reduce the total petroleum hydrocarbon pollution of groundwater in most cases.

Thus, the implementation of environmental protection measures made it possible to support oxygen saturation of groundwater during the trial. The concentration of total petroleum hydrocarbons decreased, indicating that the treatment system functioned properly. The groundwater treatment trend during the testing of the system will most likely continue in the future.

The described approach applied at the current site could also be applied at other similar sites, with adjustments depending on the natural and technogenic characteristics (geological and lithological structure, hydrogeological conditions, geomorphologic and climatic features, type of pollution, etc.). For successful and effective implementation of the proposed approach, conducting a preliminary study of the area where groundwater treatment is planned is particularly important.

It is also worth mentioning that the use of this technology will significantly improve the overall ecological condition of contaminated areas, which is a socially oriented task and an important component of the sustainable development concept. Overall, further studies on this topic are needed in the form of both research and case studies, in order to provide more details on the context and efficiency of groundwater treatment under adverse geological conditions and information on challenges and successes of similar approaches at various facilities.

Author Contributions: Conceptualization, A.D., N.M. and G.R.; methodology, A.D., N.M., V.K., A.R. and A.B.; software, A.D. and A.B.; validation, N.M. and G.R.; formal analysis, V.K. and A.R.; investigation, A.D., V.K. and A.B.; writing-original draft preparation, A.D. and V.K.; writing-review and editing, A.D., N.M., V.K. and G.R.; visualization, A.D. and V.K.; supervision, N.M. and G.R.; project administration, A.D. and A.R. All authors have read and agreed to the published version of the manuscript.

Funding: This research was funded by the Perm Research and Education Centre for Rational Use of Subsoil, 2021.

Institutional Review Board Statement: Not applicable.

Informed Consent Statement: Not applicable.

Data Availability Statement: Not applicable. 


\begin{abstract}
Acknowledgments: The authors express their sincere gratitude for the valuable contribution to scientific work to the Environmental Protection Laboratory research group of Perm State University, the Environmental Protection Department of Perm Tech, and the team of LNDC, LLC, and particular thanks to Asgat Biktimirov, Dmitriy Boyarshinov, Aleksandr Troegubov, and Aleksey Sedinin.
\end{abstract}

Conflicts of Interest: The authors declare no conflict of interest.

\title{
References
}

1. Logeshwaran, P.; Megharaj, M.; Chadalavada, S.; Bowman, M.; Naidu, R. Petroleum hydrocarbons (PH) in groundwater aquifers: An overview of environmental fate, toxicity, microbial degradation and risk-based remediation approaches. Environ. Technol. Innov. 2018, 10, 175-193. [CrossRef]

2. Ossai, I.C.; Aziz, A.; Auwalu, H.; Fauziah, S.H. Remediation of soil and water contaminated with petroleum hydrocarbon: A review. Environ. Technol. Innov. 2020, 17, 3-42. [CrossRef]

3. Truskewycz, A.; Gundry, T.D.; Khudur, L.S.; Kolobaric, A.; Taha, M.; Aburto-Medina, A.; Ball, A.S.; Shahsavari, E. Petroleum Hydrocarbon Contamination in Terrestrial Ecosystems-Fate and Microbial Responses. Molecules 2019, 24, 3400. [CrossRef] [PubMed]

4. Huling, S.G.; Weaver, J.W. Ground Water Issue: Dense Nonaquieous Liquids; United States Environmental Protection Agency: Washington, DC, USA, 1991. Available online: https://cfpub.epa.gov/si/si_public_record_report.cfm?Lab=NRMRL\&dirEntryId=12 9406 (accessed on 21 November 2021).

5. Socolov, E.M.; Maksimovich, N.G.; Meshcheriakova, O.Y. Forming oil polluting sulfate massif in karstic regions and methods of their liquidation. News Tula State Univ. Sci. Earth 2015, 2, 79-89.

6. Brusseau, M.L.; Sabatini, D.A.; Gierke, J.S.; Annable, M.D. Innovative subsurface remediation. Field testing of physical, chemical, and characterization technologies. Am. Chem. Soc. Symp. Ser. 1999, 725, 299.

7. Sabatini, D.A.; Knox, R.C.; Harwell, J.H. Surfactant-enhanced subsurface remediation. Emerging technologies. Am. Chem. Soc. Symp. Ser. 1995, 594, 300 .

8. Carey, G.R.; McBean, E.A.; Feenstra, S. DNAPL Source Depletion: 2. Attainable goals and cost-benefit analyses. Remediat. J. 2014, 24, 79-106. [CrossRef]

9. Interstate Technology Regulatory Council (ITRC). Integrated DNAPL Site Strategy. Available online: https://itrcweb.org/teams/ projects/integrated-dnapl-site-strategy (accessed on 21 November 2021).

10. Kavanaugh, M.C.; Arnold, W.A.; Beck, B.D.; Chin, Y.; Chowdhury, Z.; Ellis, D.E.; Illangasekare, T.H.; Johnson, P.C.; Mehran, M.; Mercer, J.W.; et al. Alternatives for Managing the Nation's Complex Contaminated Groundwater Sites; The National Academies Press: Washington, DC, USA, 2013; 408p.

11. Sale, T.; Parker, B.L.; Newell, C.J.; Devlin, J.F. State-of-the-Science Review: Management of Contaminants Stored in Low Permeability Zones. Strategic Environmental Research and Development Program SERDP Project ER-1740. Available online: https:/ / www.serdp-estcp.org/ (accessed on 21 November 2021).

12. Davydova, S.L.; Tagasov, V.I. Oil and Oil Products in the Environment; RUDN: Moscow, Russia, 2004; 163p.

13. Oborin, A.A.; Khmurchik, V.T.; Ilarionov, S.A.; Makarova, M.Y.; Nazarov, A.V. Oil-Polluted Biogeocenoses; UB of RAS: Perm, Russia, 2008; 511p.

14. Pryanichnikova, B.B. Electrochemical Method of Liquidation of the Consequences of Oil Pollution of Soils. Ph.D. Thesis, Ufa State Petroleum Technological University, Ufa, Russia, 2018.

15. Chen, Z.; Kuschk, P.; Reiche, N.; Borsdorf, H.; Kaestner, M.; Köser, H. Comparative evaluation of pilot scale horizontal subsurfaceflow constructed wetlands and plant root mats for treating groundwater contaminated with benzene and MTBE. J. Hazard. Mater. 2012, 209-210, 510-515. [CrossRef]

16. Chen, Z.; Kuschk, P.; Paschke, H.; Kaestner, M.; Müller, J.A.; Köser, H. Treatment of a sulfate-rich groundwater contaminated with perchloroethene in a hydroponic plant root mat filter and a horizontal subsurface flow constructed wetland at pilot-scale. Chemosphere 2014, 117, 178-184. [CrossRef] [PubMed]

17. Pandey, J.; Chauhan, A.; Jain, R.K. Integrative approaches for assessing the ecological sustainability of in situ bioremediation. FEMS Microbiol. Rev. 2009, 33, 324-375. [CrossRef] [PubMed]

18. Parmar, N.; Singh, A.; Khan, H. Bioremediation of Contaminated Sites and Aquifers. Geomicrobiol. Biogeochem. Soil Biol. 2014, 39, 261-296.

19. Trigo, A.; Valencia, A.; Cases, I. Systemic approaches to biodegradation. FEMS Microbiol. Rev. 2009, 33, 98-108. [CrossRef]

20. Maksimovich, N.G.; Khmurchik, V.T. Biotechnologies in engineering geology. Eng. Geol. 2014, 3, 18-25.

21. Maksimovich, N.G.; Meshcheriakova, O.Y.; Khmurchik, V.T. Bacterial processes in oil-polluted karst environments in Perm region (Russian Federation). In Proceedings of the IAEG/AEG Annual Meeting Proceedings, San Francisco, CA, USA, 17-21 September 2018; Springer: Cham, Switzerland; San Francisco, CA, USA, 2019; Volume 3, pp. 103-107.

22. Wilson, S.B.; Brown, R.A. In situ bioreclamation: A cost-effective technology to remediate subsurface organic contamination. Ground Water Monit. Rev. 1989, 9, 173-185. [CrossRef]

23. Foght, J.M.; Westlake, D.W.S. Bioremediation of oil spills. Spill Technol. News Lett. 1992, 17, 1-10. 
24. Koronelli, T.V. Principles and methods for Raising Efficiency of Biological degradation of hydrocarbons in the environment. Appl. Biochem. Microbiol. 1996, 32, 579-585.

25. Atlas, R.M. Microbial Degradation of Petroleum Hydrocarbons: An Environmental Perspective. Microbiol. Rev. 1981, 45, 180-209. [CrossRef] [PubMed]

26. Maksimovich, N.G.; Khmurchik, V.T.; Meshcheriakova, O.Y. Ground waters clarification experience from oil pollution by biological methods. Ind. Saf. Ecol. 2009, 4, 34-36.

27. Maksimovich, N.G.; Khmurchik, V.T. Consortium of Strains of Hydrocarbon-Oxidizing Bacteria Pseudomonas aeruginosa ND K3-1 and Pseudomonas fluorescens ND K3-2 as Hydrocarbon Destructor and a Method of Treating Oil-Polluted Subsurface Waters. Patent RU 2312719 C1, 20 December 2007.

28. Maksimovich, N.G.; Khmurchik, V.T. Remediation of oil-polluted groundwater aquifers at karst region. In Engineering Geology for Society and Territory; River basins, reservoir sedimentation and water resources; Springer: Cham, Switzerland, 2015; Volume 3, pp. 417-419.

29. Kaiser, J.-P.; Bollag, J.-M. Microbial activity in the terrestrial subsurface. Cell. Mol. Life Sci. 1990, 46, 797-806. [CrossRef]

30. Aburto, A.; Fahy, A.; Coulon, F.; Lethbridge, G.; Timmis, K.N.; Ball, A.S.; McGenity, T.J. Mixed aerobic and anaerobic microbial communities in benzene-contaminated groundwater. J. Appl. Microbiol. 2009, 106, 317-328. [CrossRef]

31. Hao, R.; Lu, A. Biodegradation of heavy oils by halophilic bacterium. Prog. Nat. Sci. 2009, 19, 997-1001. [CrossRef]

32. Yagi, J.M.; Neuhauser, E.F.; Ripp, J.A.; Mauro, D.M.; Madsen, E.L. Subsurface ecosystem resilience: Long-term attenuation of subsurface contaminants supports a dynamic microbial community. ISME J. 2010, 4, 131-143. [CrossRef] [PubMed]

33. Cost Analyses for Selected Groundwater Cleanup Projects: Pump and Treat Systems and Permeable Reactive Barriers; US Environmental Protection Agency: Washington, DC, USA, 2001. Available online: https://www.epa.gov/remedytech/cost-analyses-selectedgroundwater-cleanup-projects-pump-and-treat-systems-and-permeable (accessed on 21 November 2021).

34. Cost-Effective Design of Pump and Treat Systems; US Environmental Protection Agency: Washington, DC, USA, 2005. Available online: https:/ / www.epa.gov/remedytech/cost-effective-design-pump-and-treat-systems (accessed on 21 November 2021).

35. Nwachukwu, M.A. Prospective techniques for in situ treatment and protection of aquifers: A sustainable hydrology review. Int. J. Water Res. Environ. Eng. 2014, 6, 131-143.

36. Juwarkar, A.A.; Misra, R.R.; Sharma, J.K. Recent trends in bioremediation. Geomicrobiol. Biogeochem. Soil Biol. $2014,39,81-100$.

37. Tyagi, M.; da Fonseca, M.M.R.; de Carvalho, C.C.C.R. Bioaugmentation and biostimulation strategies to improve the effectiveness of bioremediation processes. Biodegradation 2011, 22, 231-241. [CrossRef]

38. Innovative Remediation Technologies: Field-Scale Demonstration Projects in North America, 2nd ed.; US Environmental Protection Agency: Washington, DC, USA, 2000. Available online: https://www.epa.gov/remedytech/innovative-remediationtechnologies-field-scale-demonstration-projects-north-america-2nd (accessed on 21 November 2021).

39. Gibson, T.L.; Abdul, A.S.; Chalmer, P.D. Enhancement of in situ bioremediation of BTEX-contaminated ground water by oxygen diffusion from silicone tubing. Groundwater Monit. Remediat. 1998, 18, 93-104. [CrossRef]

40. Kashir, M.; Barker, J.; McGregor, R.; Shouakar-Stash, O. Aerobic Biodegradation of Hydrocarbons in High Temperature and Saline Groundwater. Remediat. J. 2014, 24, 77-90. [CrossRef]

41. Wilson, R.D.; Mackay, D.M.; Scow, K.M. In situ MTBE biodegradation supported by diffusive oxygen release. Environ. Sci. Technol. 2002, 36, 190-199. [CrossRef]

42. McHugh, T.E.; Kulkarni, P.R.; Newell, C.J.; Connor, J.A.; Garg, S. Progress in Remediation of Groundwater at Petroleum Sites in California. Groundwater 2014, 52, 898-907. [CrossRef]

43. Salanitro, J.P.; Johnson, P.C.; Spinnle, G.E.; Maner, P.M.; Wisniewski, H.L.; Bruce, C. Field-scale demonstration of enhanced MTBE bioremediation through aquifer bioaugmentation and oxygenation. Environ. Sci. Technol. 2000, 34, 4152-4162. [CrossRef]

44. Scow, K.M.; Hicks, K.A. Natural attenuation and enhanced bioremediation of organic contaminants in groundwater. Curr. Opin. Biotechnol. 2005, 16, 246-253. [CrossRef] [PubMed]

45. Smith, A.E.; Hristova, K.; Wood, I.; Mackay, D.M.; Lory, E.; Lorenzana, D.; Scow, K.M. Comparison of biostimulation versus bioaugmentation with bacterial strain PM1 for treatment of groundwater contaminated with methyl tertiary butyl ether (MTBE). Environ. Health Perspect. 2005, 113, 317-322. [CrossRef]

46. Robertson, W.D.; Cherry, J.A. Long term performance of the Waterloo denitrification barrier. In Proceedings of the International Containment Technology Conference Proceedings, St. Petersburg, FL, USA, 9-12 February 1997; US Department of Energy: Washington, DC, USA, 1997; pp. 691-696.

47. Wilson, R.D.; Mackay, D.M. Arrays of unpumped wells: An alternative to permeable walls for in situ treatment. In Proceedings of the International Containment Technology Conference proceedings, St. Petersburg, FL, USA, 9-12 February 1997; US Department of Energy: Washington, DC, USA, 1997; pp. 888-894.

48. Davis, L.C.; Erickson, L.E. A review of bioremediation and natural attenuation of MTBE. Environ. Prog. 2004, $23,243-252$. [CrossRef]

49. Rodríguez-Martínez, E.M.; Pérez, E.X.; Schadt, C.W.; Zhou, J.; Massol-Deyá, A.A. Microbial diversity and bioremediation of a hydrocarbon-contaminated aquifer (Vega Baja, Puerto Rico). Int. J. Environ. Res. Public Health 2006, 3, 292-300. [CrossRef]

50. Chapelle, F.H. Bioremediation of petroleum hydrocarbon-contaminated ground water: The perspectives of history and hydrology. Groundwater 1999, 37, 122-132. [CrossRef] 
51. Yaniga, P.M.; Matson, C.; Demko, D.J. Restoration of water quality in a multi-aquifer system via in situ biodegradation of the organic contaminants. In Proceedings of the Fifth National Symposium and Exposition on Aquifer Restoration and Ground Water Monitoring, Worthington, OH, USA, 21-24 May 1985; National Water Well Association: Worthington, OH, USA, 1985. 510p.

52. Wilson, R.D.; Mackay, D.M. A method for passive release of solutes from an unpumped well. Ground Water 1995, 33, 936-945. [CrossRef]

53. Baldwin, B.R.; Nakatsu, C.H.; Nies, L. Enumeration of aromatic oxygenase genes to evaluate monitored natural attenuation at gasoline-contaminated sites. Water Res. 2008, 42, 723-731. [CrossRef] [PubMed]

54. Wilson, R.D.; Mackay, D.M.; Cherry, J.A. Arrays of unpumped wells for plume migration control by semi-passive in situ remediation. Groundwater Monit. Remediat. 1997, 17, 186-194. [CrossRef]

55. Chapman, S.W.; Byerley, B.T.; Smyth, D.J.A.; Mackay, D.M. A pilot test of passive oxygen release for enhancement of in situ bioremediation of BTEX-contaminated ground water. Groundwater Monit. Remediat. 1997, 17, 93-105. [CrossRef]

56. Brzeszcz, J.; Kapusta, P.; Steliga, T.; Turkiewicz, A. Hydrocarbon Removal by Two Differently Developed Microbial Inoculants and Comparing Their Actions with Biostimulation Treatment. Molecules 2020, 25, 661. [CrossRef]

57. Płaza, G.A.; Jangid, K.; Lukasik, K.; Nałecz-Jawecki, G.; Berry, C.J.; Brigmon, R.L. Reduction of Petroleum Hydrocarbons and Toxicity in Refinery Wastewater by Bioremediation. Bull. Environ. Contam. Toxicol. 2008, 81, 329-333. [CrossRef]

58. Dueholm, M.S.; Marques, I.G.; Karst, S.M.; D'imperio, S.; Tale, V.P.; Lewis, D.; Nielsen, P.H.; Nielsen, J.L. Survival and activity of individual bioaugmentation strains. Bioresour. Technol. 2015, 186, 192-199. [CrossRef] [PubMed]

59. Christensen, T.H.; Kjeldsen, P.; Bjerg, P.L.; Jensen, D.L.; Christensen, J.B.; Baun, A.; Albrechtsen, H.J.; Heron, G. Biogeochemistry of landfill leachate plumes. Appl. Geochem. 2001, 16, 659-718. [CrossRef] 